\title{
Norsk karkirurgi i «karkirurgiens år»
}

I dette nummer av Tidsskriftet introduseres en temaserie der leserne gis en oppdatering $\mathrm{i}$ internasjonal og nasjonal karkirurgi. Serien inngår i en rekke begivenheter som markerer «karkirurgiens år» i Norge. Hensikten med dette «året» og denne temaserien er å sette søkelys på en pasientgruppe som hittil har fått liten oppmerksomhet og som øker i volum på grunn av at det blir flere eldre. I tillegg ønsker man å gi informasjon til publikum og beslutningstakere.

De første behandlinger av aortaaneurisme med stentgraft i Norge ble utført i 1995. Dette var et stort fremskritt, og omtrent halvparten av pasientene kan behandles med denne metoden. Som påpekt av Vetrhus og medarbeidere trenger vi flere langtidsresultater for å finne frem til de rette indikasjonene for stentgrafting (1). Risikoen for komplikasjoner nødvendiggjør nøye oppfølging av pasientene. Tromsø-undersøkelsen har gitt oss verdifull informasjon om forekomsten av aortaaneurisme (2) og om at aneurismeveksten skjer raskere hos kvinner, som også har høyere dødelighet ved operativ behandling. Flere studier viser redusert aneurismerelatert dødelighet hos menn i aldersgruppen 65-79 år som ble rutinemessig undersøkt (screening) og behandlet sammenliknet med en kontrollgruppe. Vi mener derfor at det er berettiget når Jarlis Wesche anbefaler at et slikt screeningprogram igangsettes i Norge (3). Det er flere forhold som er med på å predisponere for utviklingen av aneurisme, f.eks. røyking og høyt blodtrykk. Nyere forskning viser også at det foreligger en genetisk disposisjon (4).

Torakoabdominale aneurismer omfatter både torakal- og abdominalaorta. Nyere studier har vist at stentgraftbehandling med sidearmer til nyrearteriene og de viscerale arterier kan være et alternativ, men behandlingen er komplisert. Fortsatt er åpen kirurgi gullstandarden for behandling av denne tilstanden.

Når det gjelder varicer, har man tatt i bruk nyere metoder som radiofrekvensbehandling, laserbehandling og injeksjon av skleroserende skum (5). Oppfølgingstiden er for kort til at man kan si noe sikkert om residivfrekvensen, som ved konvensjonell operasjon (stripping og lokal ekstirpasjon) er på opptil 50\% etter 5-10 år. Ved insuffisiens av de dype veneklaffene kan klaffeplastikk eller autotransplantasjon være et alternativ. Foreløpig er det bare få pasienter som er aktuelle for denne behandlingen.

Pasienter med claudicatio intermittens pga. aterosklerose i underekstremitetene trenger først og fremst kontroll av risikofaktorer, instituering av medikamentell terapi, røykeavvenningsprogram og systematisk gangtrening. Erfaringen er at slike tiltak vil bedre eller stabilisere den kliniske tilstanden hos mer enn $50 \%$ av disse. Flørenes og medarbeidere anbefaler at man dernest bør vurdere endovaskulær terapi som førstevalg før bypass både ved claudicatio intermittens og kritisk iskemi (6). Prinsipielt støtter vi denne anbefalingen. Dette er imidlertid vanskelig å innføre på nasjonalt nivå, da tilgangen på endovaskulær behandling ikke er like god ved alle karkirurgiske avdelinger, blant annet på grunn av mangel på kvalifisert personell.

De aller fleste pasienter med TIA-anfall bør undersøkes raskt eller som øyeblikkelig hjelp og utredes, blant annet med dupleksskanning av halsarteriene (7). Plateaggregasjonshemmer skal gis umiddelbart. Ved stenoser på over $50 \%$ på den relevante sides a. carotis interna kan det være indikasjon for endarterektomi for å redusere risikoen for hjerneslag. Man bør sette inn forebyggende tiltak som røykeavvenning og adekvat medikamentell behandling rettet mot eventuelle risikofaktorer som høyt blodtrykk, diabetes mellitus og metabolsk syndrom. Stenting av carotisstenose er blitt brukt en del $\mathrm{i}$ andre land, i Norge hovedsakelig som ledd i vitenskapelige undersøkelser. Behandling av asymptomatisk carotisstenose er kontroversielt. Selv om det er påvist en viss effekt av operasjon i enkelte undersøkelser, er det sjelden man tilbyr kirurgisk behandling for asymptomatiske carotisstenoser her i landet.

Etter vår mening har norsk karkirurgi bra kvalitet når det gjelder kliniske resultater. Vi bør imidlertid intensivere det ikke-kirurgiske arbeidet, altså forebygging og optimal medikamentell behandling. Faglig validert pasientinformasjon bør forbedres. I så måte er nettsiden til Norsk karkirurgisk forening et forbilde (8). Sammenliknet med tilsvarende registre i Skandinavia kunne vårt norske, Norkar, vært kvalitetsmessig bedre. Det er fortsatt mangelfull rapportering og delte oppfatninger av verdien av dette registeret blant våre kolleger. Obligatorisk deltakelse bør vurderes, og verdien av slike registre diskuteres. Forskningsaktiviteten kunne volummessig vært høyere sammenliknet med aktiviteten i de øvrige nordiske land. Det er muligens fordi det kliniske arbeid prioriteres.

Det er behov for en bred tilnærming til pasienter med karlidelser. Ofte har personer med perifer aterosklerotisk sykdom også affeksjon i andre deler av arteriesystemet. Det bør være minst ett avansert karlaboratorium i hver helseregion. Utredning, behandling og oppfølging krever tverrfaglig kompetanse, der karkirurg, vaskulær intervensjonsradiolog og karfysiologiske tjenester må ha en sentral plass.

\section{Hans Olav Myhre \\ hans.myhre@ntnu.no \\ Jørgen J. Jørgensen \\ j.j.jorgensen@medisin.uio.no}

Hans Olav Myhre (f. 1939) er dr.med., overlege ved kirurgisk klinikk, St. Olavs hospital, og professor i kirurgi ved Norges teknisk-naturvitenskapelige universitet.

Jørgen J. Jørgensen (f. 1947) er dr.med., overlege ved Oslo Vaskulære Senter, Oslo universitetssykehus, Aker, og professor i karkirurgi ved Universitetet i Oslo.

Oppgitte interessekonflikter: Ingen

\section{Litteratur}

1. Vetrhus M, Viddal B, Loose $\mathrm{H}$ et al. Abdominale aortaaneurismer - endovaskulær og åpen kirurgi. Tidsskr Nor Legeforen 2009; 129: akseptert for publisering.

2. Singh K, Bønaa KH, Jacobsen BK et al. Prevalence and risk factors for abdominal aortic aneurysms in a population-based study. The Troms $\varnothing$ Study. Am J Epidemiol 2001: 154: 236-44.

3. Wesche J. Epidemiologi, utredning og behandlingsindikasjon ved aortaaneurisme. Tidsskr Nor Legeforen 2009; 129: 2124-6.

4. Elmore JR, Obmann MA, Kuivaniemi $\mathrm{H}$ et al. Identification of a genetic variant associated with abdominal aortic aneurysms on chromosome $3 p 12.3$ by genome wide association. J Vasc Surg 2009; 49: 1525-31.

5. Van den Bos, Arends L, Kockaert M et al. Endovenous therapies of lower extremity varicosities: a meta-analysis. J Vasc Surg 2009; 49: 230-9

6. Flørenes T, Sandbæk G. Stranden E et al. Kirurgisk behandling av perifer aterosklerose I underekstremitetene. Tidsskr Nor Legeforen 2009: 129: akseptert for publisering

7. Krohg-Sørensen K, Lingaas PS, Bakke SJ et al. Åpen kirurgi og endovaskulær behandling av carotisstenose. Tidsskr Nor Legeforen 2009; 129: akseptert for publisering.

8. www.karkirurgi.org 